\title{
The Influence Of Brand Experience On Brand Satisfaction, Trust And Attachment In South Africa
}

Richard Chinomona, Vaal University of Technology, South Africa

\begin{abstract}
This study examines the influence of consumer brand experience on their brand satisfaction, brand trust and brand attachment in an African context. Five hypotheses are posited and in order to empirically test them, a sample data set of 151 was collected from Gauteng Province of South Africa. The results indicate that brand experience positively influences brand satisfaction, brand trust and brand attachment in a significant way. Drawing from the study's findings, managerial implications are discussed and limitations and future research directions are suggested. By and large, this study immensely contributes new knowledge to the existing body of brand management literature in Africa - a context that is often most neglected by some researchers in developing countries.
\end{abstract}

Keywords: Brand Experience; Brand Satisfaction; Brand Trust; Brand Attachment; South Africa

\subsection{INTRODUCTION}

lthough the notion of brand attachment can be traced to Bowlby (1979), brand attachment paradigm is relatively a new development that is yet to mature (Tsai, 2011). As a result, brand attachment has attracted interest from both academic researchers and practitioners in the marketing discipline (Nguyen \& John, 2005; Thomson, 2006; Park \& MacInnis 2006; Fedorikhin, Park, \& Thomson, 2008; Park et al. 2009). According to Park, MacInnis, Priester, Eisingerich and Iacobucci (2010), brand attachment describes the strength of the bond connecting the consumer with the brand. Brand attachment is important to marketers because it affects repurchase behaviors that foster brand profitability and customer lifetime value (Thomson, MacInnis \& Park, 2005). Customers who repeatedly purchase brands contribute to consistent revenue streams and sustained profit (Fedorikhin, Park \& Thomson, 2008). As a result of this, business enterprises often implement programs that facilitate consumer brand attachment (Büschken, 2004; Thomson, MacInnis, \& Park, 2005; Carroll \& Ahuvia 2006). Also because of this recognized importance, academicians have developed keen interest in the empirical investigation of brand attachment antecedents (Gillath, Shaver, Baek \& Chun, 2008; Bell, 2010).

However, a cross examination of the existing spate of brand management literature seems to show that most of these studies focused on, among others, sentimentality, socialization, superior marketing characteristics, user-derived benefits, brand commitment, trust, satisfaction, self-concept connection, aesthetic attractiveness, and delight as antecedents of brand attachment (Kuenzel \& Halliday, 2008; Grisaffe \& Nguyen, 2011; Tsai, 2011). Despite this, there seem to be a lack of studies that investigated the influence of brand experience as an important predictor of brand attachment (Mzoughi, Hadiji \& Slimane, 2009; Sahina, Zehirb \& Kitapç, 2011). Marketing practitioners have come to realize that understanding how consumers experience brands is critical for developing marketing strategies for goods and services (Chattopadhyay \& Laborie, 2005; Schmitt, 2003; Shaw \& Ivens, 2002; Smith \& Wheeler, 2002). Brand experience, according to Brakus, Schmitt and Zarantonello (2009), refers to subjective, internal consumer responses (sensations, feelings, and cognitions) and behavioral responses evoked by brand-related stimuli that are part of a brand's design and identity, packaging, communications, and environments (Brakus, Schmitt \& Zhang, 2008). According to Sahina, Zehirb and Kitapç (2011), prior experience with a brand has a substantial impact on brand choice for subsequent purchases. Thus, attitudes toward the brand are primarily 
formed after the first purchase. This evaluation, in turn, is used as pre-evaluation for repeat purchases. Brand loyalty is thus developed through the experience of repurchasing a brand over time (Ercis, Unal, Candan \& Yildrinm, 2012). Given the influence of brand experience on, for instance, brand attitude, brand loyalty, commitment and brand performance, it is surprising that brand experience has rarely been empirically tested as a potential predictor of brand attachment.

Against this backdrop, the purpose of the current study is to fill this void by investigating the influence of brand experience on brand attachment. Furthermore, this study seeks to explore the moderating role of brand satisfaction and brand trust in this brand experience - brand attachment relationship in the context of South Africa. Besides, the current study is expected to make academic and practical contributions to the existing marketing management literature and the practice of branding in developing countries - South Africa in particular.

This paper consists of sections presenting literature review; research methodology, which includes data collection procedure, construct operationalization, and measurement; data analysis and results; discussion and implications of the study findings; a conclusion; limitations of the study; and suggestions for future research.

\subsection{LITERATURE REVIEW}

\subsection{Brand Experience}

There is growing evidence from marketing researching indicating that branding exposes customers or consumers to various specific brand-related stimuli, such as brand-identifying colors (Ofir \& Simonson, 2007), shapes (Veryzer \& Hutchinson, 1998; Joy \& Sherry, 2003), typefaces, background design elements (Mandel \& Johnson, 2002), and slogans, mascots, and brand characters (Johar, Sengupta, \& Aaker, 2005). These brand-related stimuli appear as part of a brand's design and identity (e.g., name, logo, signage), packaging, and marketing communications (e.g., advertisements, brochures, websites) and in environments in which the brand is marketed or sold (e.g., stores, events). While these brand-related stimuli constitute the major source of subjective and internal consumer responses, the main evaluation of a service occurs after consumption (Arnold, Reynolds, Ponder \& Lueg, 2005). Brand experience is a personal source of information that can be utilized to form the basis of future decisions, such as repurchase intention (Brakus, Schmitt, \& Zhang, 2008). This notion is buttressed by Sahina, Zehirb and Kitapç (2011) who found out that prior experience with a service has a substantial impact on brand choice for subsequent purchases of the service. Thus, attitudes toward the brand are primarily formed after the first purchase. This evaluation, in turn, is used as pre-evaluation for repeat purchases. Brand loyalty is thus developed through the experience of repurchasing a brand over time (Ercis, Unal, Candan \& Yildrinm, 2012). Consistent with this notion are findings that show that the more frequent the prior experience, the stronger the attitude (Grace \& O'Cass, 2004). An understanding of the role of previous experience with a purchase decision is therefore critical to an understanding of the development of attitudinal brand loyalty. In this study, brand experience is defined according to Brakus, Schmitt \& Zarantonello (2009) who expressed it as subjective, internal consumer responses and behavioral responses evoked by brand-related stimuli that are part of a brand's design and identity, packaging, communications, and environments.

\subsection{Brand Satisfaction}

Many studies have been conducted on brand satisfaction (e.g. Kuenzel and Halliday, 2008; Kuenzel \& Halliday, 2008; Grisaffe \& Nguyen, 2011; Tsai, 2011). Among some of the identified antecedents of satisfaction in the extant literature are functional, symbolic, and experiential benefits (Nam, Ekinci \& Whyatt, 2011). It is argued, in the literature, that via the mediating influence of brand attributes, past consumption experiences affect brand satisfaction (Jones \& Suh, 2000; Pappu \& Quester, 2006). At the same time, some empirical studies have treated brand attitudes as a consequence of brand satisfaction (Cooil, Keiningham, Aksoy, \& Hsu, 2007). According to He, $\mathrm{Li}$ and Harris (2012), satisfaction occurs when the performance of a brand meets the expectations of the purchaser. If performance fails to meet expectations, negative disconfirmation occurs, which results in dissatisfaction (Patterson, Johnson \& Spreng, 1997). In this token, Nam, Ekinci and Whyatt (2011) described brand satisfaction as an evaluative summary of direct consumption experience, based on the discrepancy between prior expectation and the actual performance perceived after consumption (Kuenzel \& Halliday, 2008). However, in the current study, 
brand satisfaction is defined according to Grisaffe \& Nguyen (2011) who expressed it as the cumulative satisfaction as overall consumer's evaluation based on the consumer's total purchase and experience with a brand of product or service.

\subsection{Brand Trust}

Brand trust is "the willingness of the average consumer to rely on the ability of the brand to perform its stated function" (Chaudhuri \& Holbrook, 2001; Schau, Muniz \& Arnould, 2009). This notion is more prominent in situations of uncertainty, information asymmetry, and fear of opportunism; thus, the role of trust is to decrease uncertainty and information asymmetry and make customers feel comfortable with their brand (Chiu, Huang, \& Yen, 2010; Gefen, Karahanna, \& Straub, 2003; Pavlou, Liang, \& Xue, 2007). In marketing literature, trust is regarded as a key ingredient for the development of brand attachment and has been recognized as a highly significant tool for enhancing brand performance (Carroll \& Ahuvia, 2006; McAlexander, Schouten \& Koenig, 2002; Ruyter, Moorman \& Lemmink, 2001). These literatures noted that repeated interactions with a brand and brand experience are keys to building trust (Wang \& Emurian, 2005; Schau et al., 2009). In fact, according to Zhou, Zhang, Su \& Zhou (2012), the increased level of interactions between consumers and the brand is a value creating practice which makes them trust and love a brand. In this study, brand trust is defined as the willingness of the average consumer to rely on the ability of the brand to perform its stated function (Wang \& Emurian, 2005).

\subsection{Brand Attachment}

As noted by Tsai (2011), the notion of brand attachment has its roots in the interpersonal attachment theory, which was originated by Bowlby (1979) but further developed by Simpson, Collins, Tran, and Haydon (2007), Gillath, Shaver, Baek, and Chun (2008) and Bell (2010), among others. This theory propounds that attachment to figures is an inborn behavioral system (Tsai, 2011). Applied to the brand attachment paradigm, the theory subjected that customers have an innate propensity to be attached to some brands (Pawle \& Cooper, 2006; Parish \& Holloway, 2010). It is argued, in the extent literature, that consumers, in particular, develop passionate love for certain brands which eventually lead to brand attachment (Fedorikhin, Park, \& Thomson, 2008; Park, Macinnis \& Priester, 2009). In this vein, four indicators of passionate love and brand attachment are posited to be 1) a right physical chemistry between the brand and the consumer, 2) the brand and the consumer meant for each other, 3) the brand fits the ideal standard of the consumer's self-image, and 4) the consumer feels miserable if the brand is not available (Tsai, 2011). While Thomson, MacInnis, and Park (2005) believe that brand attachment is related to the association between hedonism and self-expressiveness, Albert, Merunka, and Valette-Florence (2008) expand this scope to capture eleven dimensions of brand attachment; namely, passion, duration, self-congruity, dreams, memories, pleasure, attraction, uniqueness, beauty, trust, and declaration of affect. However, according to Park, Maclnnis, Priester, Eisingerich \& Lacobucci (2010), a brand that scores high on reputation, performance, trust, commitment, sensuality, intimacy, passion, and mystery becomes the love-marks brand. In this regard, such a brand may command heightened intensity of brand attachment, regardless of which category the brand belongs (Tsai, 2011).

\subsection{CONCEPTUAL MODEL AND HYPOTHESIS DEVELOPMENT}

In order to empirically test the influence of brand experience on brand satisfaction, brand trust and brand attachment, a conceptual model is developed premised on the reviewed brand management literature. In this conceptualized model, brand experience is the predictor variable, while brand satisfaction and brand trust are the mediators, and brand attachment is the single outcome variable. Figure 1 depicts this conceptualized research model. The hypothesized relationships between the research constructs will be discussed hereafter. 


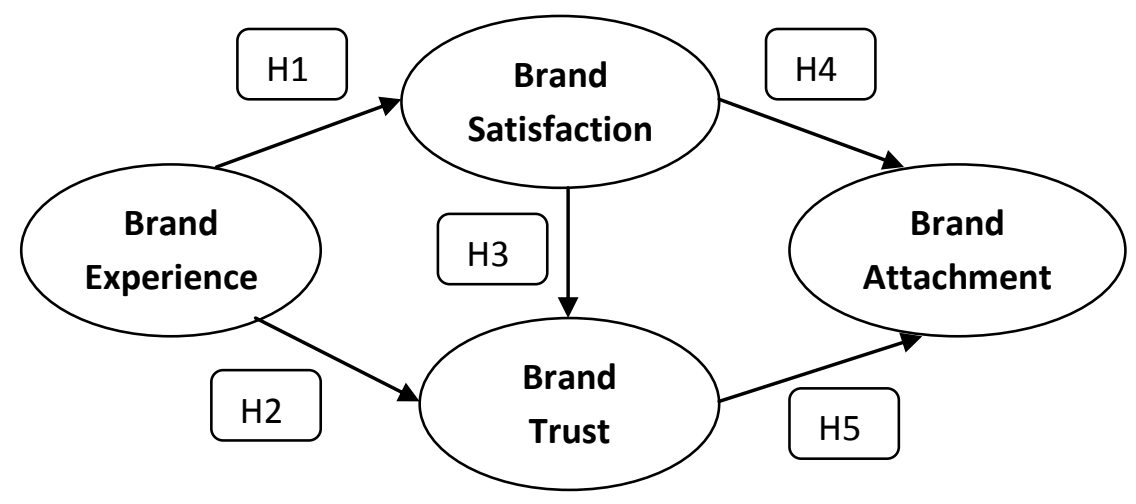

Figure 1: Conceptual Model

\subsection{Brand Experience, Brand Satisfaction and Brand Trust}

Drawing from the extant brand management literature, it is submitted that a positive brand experience tends to generate a positive emotional and cognitive state, which eventually leads to psychological satisfaction with that brand (Kim, 2005). This positive brand experience occurs when the net value of good interactions with the brand exceeds the value of negative ones (Christodoulides, De Chernatony, Furrer, Shiu, Abimbola, 2006). According to Janda \& Ybarra (2006), it is this perceived net value that leads to satisfaction with the brand. Thus, when perceived value emanating from brand experience is high, satisfaction also gets high (Meyer \& Schwager, 2007). However, in a study by Chaudhuri and Holbrook (2001), they also found a positive association between the perceived brand value and trust. There is also growing evidence in the extant literature indicating that a positive brand experience necessitates future repurchase and the higher the positive experience from these repetitive purchases, the more the customers tend to trust the brand (Koufaris, 2002; Kim, 2005; Flavian \& Guinaliu, 2006). Therefore, the higher the degree of positive brand experience the customers realize, the more they are satisfied and tend to trust that brand. Prior empirical evidence has found a positive relationship between brand experience and satisfaction and between brand experience and trust (Janda \& Ybarra, 2006; Kim, 2005; Flavian \& Guinaliu, 2006; Meyer \& Schwager, 2007). Accordingly, drawing from the forgoing debate and empirical evidence, it can be expected that brand experience is positively associated to customer brand satisfaction and brand in South Africa. Therefore, it can be posited that:

H1: Brand experience is positively related to brand satisfaction in South Africa.

H2: Brand experience is positively related to brand trust in South Africa.

\subsection{Brand Satisfaction and Brand Trust}

The relationship between satisfaction and trust has been widely researched in marketing literature (Kuenzel \& Halliday, 2008; Wang \& Emurian, 2005; Schau, Muniz \& Arnould, 2009). While there seems to me no consensus on the direction of causality, in the current study it is postulated that customer satisfaction with a brand should eventually lead them trusting that brand. According to Nam, Ekinci \& Whyatt (2011), satisfaction with brand consumption generates a positive attitude toward that brand, which culminates in brand trust. Brand trust, in this vein, expresses the belief of consumers that the experienced brand satisfaction will continue to be fulfilled by the brand (Zhou, Zhang, Su \& Zhou, 2012). Thus, the higher the degree of brand satisfaction the customer realizes, the higher the level of brand trust. Previous researchers have found a positive relationship between brand satisfaction and brand trust (Whang, Allen, Sahoury \& Zhang, 2004; Suh \& Han, 2003; Yoon, 2002; Kuenzel \& Halliday, 2008). Similarly, deducing from the aforementioned discussion and empirical evidence, it can be expected that brand satisfaction is positively associated to customer brand trust in South Africa. Therefore, it can be posited that:

H3: Brand satisfaction is positively related to brand trust in South Africa. 


\subsection{Brand Satisfaction, Brand Trust and Brand Attachment}

Amounting evidence from marketing management literature testifies that the more satisfied consumers are with a brand, the greater the identification of consumers with that brand because the essence of satisfaction is fulfillment (Bhattacharya \& Sen, 2003; Kuenzel \& Halliday, 2008). According to Chiu, Huang \& Yen (2010), highly satisfied consumers tend to reflect the brand personality traits by using some symbols related to the brand as an expression of their attachment to that brand. Similarly, consumers who trust a brand are willing to improve and sustain an affective bond with the brand that makes them feel warm and enjoyable. Eventually, a stronger affective bond culminates in brand attachment (Büschken, 2004; Keh, Nguyen \& Ng, 2007). Therefore, the higher the level of brand satisfaction the customer experience, the more they are likely to be attached to the brand. Similarly, higher level brand trust can be expected to lead to a stronger brand attachment. Prior studies have found a positive relationship between brand satisfaction and attachment and between brand trust and attachment (Keh et al., 2007; Kuenzel \& Halliday, 2008; Chiu et al., 2010; Kim, Chung, \& Lee, 2011). Consequently, premised on the forgoing discussion and empirical evidence, it can be expected that brand satisfaction and trust are positively associated to customer brand attachment in South Africa. Therefore, it can be hypothesized that:

H4: Brand satisfaction is positively related to brand attachment in South Africa.

H5: Brand trust is positively related to brand attachment in South Africa.

\subsection{RESEARCH METHODOLOGY}

\subsection{Sample and Data Collection}

The target population for the study was South African consumer in Gauteng who purchased any consumer goods. The sampling unit was the individual consumer and a mall intercept survey was used. This method has the advantage of speed, is less costly, and the researcher has control over respondent type. Four shopping malls in Vanderbijlpark were selected for this survey and students from the Vaal University of Technology were recruited as research assistants to distribute and collect the questionnaires. Of the total of 170 questionnaires distributed, 151 usable questionnaires were retrieved for the final data analysis, representing a response rate of 89 percent. To eliminate differences in response patterns due to different reference points, all respondents were prompted to answer the questionnaire with reference to non-durable consumer goods. The reason for selecting this category was that consumers frequently purchase these products. In this regard, the respondents were asked to identify a product category in which they had frequently made a purchase intention decision. Respondents were then asked to name a brand in that category and they were requested to think about that brand as they completed the entire questionnaire, guided by the research assistants.

\subsection{Measurement Instrument and Questionnaire Design}

Research scales were operationalized on the basis of previous work. Proper modifications were made in order to fit the current research context and purpose. "Brand experience" measure used a twelve-item scale while "Brand satisfaction" used an eight-item scale, all adapted from Sahina, Zehir and Kitapç (2011). "Brand trust" used a four-item scale measure adopted from He, Li and Harris (2012). Finally, "Brand attachment" was measured using a four-item scale adapted from Tsai (2011). All the measurement items were measured on a five-point Likert-type scale that was anchored by $1=$ strongly disagree to $5=$ strongly agree to express the degree of agreement. Individual scale items are listed in the Appendix.

\subsection{Respondent Profile}

Table 1 presents the description of the participants. The respondents were asked to report their demographic information, including gender, age, marital status and education. The respondents were predominantly females (57.6\%). The median age group of the respondent was that of less than 30 years $(54.3 \%)$ and $57 \%$ of the respondents were single. About $71 \%$ of the respondents had either high school $(43.7 \%)$ or university level of education $(27.2 \%)$ and the remainder had primary school (19.9) or postgraduate level of education $(0.09 \%)$. 
Table 1: Sample Demographic Characteristics

\begin{tabular}{|c|c|c|}
\hline Gender & Frequency & Percentage \\
\hline Male & 64 & $42.4 \%$ \\
\hline Female & 87 & $57.6 \%$ \\
\hline Total & 151 & $100 \%$ \\
\hline Age & Frequency & Percentage \\
\hline$\leqq 30$ & 82 & $54.3 \%$ \\
\hline $31-60$ & 51 & $33.8 \%$ \\
\hline$\geqq 60$ & 18 & $11.9 \%$ \\
\hline Total & 151 & $100 \%$ \\
\hline Marital Status & Frequency & Percentage \\
\hline Married & 65 & $43.0 \%$ \\
\hline Single & 86 & $57.0 \%$ \\
\hline Total & 151 & $100 \%$ \\
\hline Level of Education & Frequency & Percentage \\
\hline Primary School & 30 & $19.9 \%$ \\
\hline High School & 66 & $43,7 \%$ \\
\hline University & 41 & $27.2 \%$ \\
\hline Postgraduate & 14 & $0.09 \%$ \\
\hline Total & 151 & $100 \%$ \\
\hline
\end{tabular}

\subsection{DATA ANALYSIS}

The purpose of this section is to statistically analyze the research model and test our hypotheses. In order to assess the measurement model and the structural model, the researcher used Smart PLS software - a PLS-based structural equation modeling (SEM) technique. According to Koçoglu, Imamoglu, Ince and Keskin (2011), the measurement model refers to the linkages between the research constructs (latent variables) and their indicators (manifest variables), while the structural model captures the hypothesized causal relationships among the research constructs. Smart PLS has emerged as a powerful approach to study causal models involving multiple constructs with multiple indicators (Liljander, Polsa \& van Riel, 2009). Among some of the strengths of Smart PLS approach to SEM are its ability to model latent constructs that are uncontaminated by measurement error under conditions of non-normality and small-to-medium sample sizes and to handle complex predictive models, which is preferable to techniques, such as regression, which assumes error-free measurement (Ringle, Wende \& Will, 2005). Besides, Smart PLS approach is the most appropriate SEM approach to use when the aims of the study are predictive applications and/or theory-building (Chin \& Newsted, 1999). Since the current study sample size is relatively small (151), Smart PLS was found more appropriate and befitting the purpose of the current study.

\subsection{Measurement Model}

The researcher checked the measurements reliability and validity. Reliability was mainly checked using the Composite Reliability (CR) and Cronbach's alpha value. To ensure convergent validity, the researcher checked whether items loaded on their respective (a priori) constructs with loadings greater than 0.5 . Discriminant validity was checked by Average Variance Extracted (AVE) value, ensuring that there were no significant inter-research variables cross-loadings (Chin 1998). Smart PLS performs a Confirmatory Factor Analysis (CFA) while estimating the structural model (SEM). The CFA results are reported in Table 2 and Figure 2, while the SEM results are presented in Table 4 and Figure 2. 
Table 2: Accuracy Analysis Statistics

\begin{tabular}{|c|c|c|c|c|c|c|c|c|}
\hline \multicolumn{2}{|c|}{$\begin{array}{l}\text { Research } \\
\text { Construct }\end{array}$} & $\begin{array}{c}\text { LV Index } \\
\text { Value }\end{array}$ & $\begin{array}{l}\text { R-Squared } \\
\text { Value }\end{array}$ & $\begin{array}{c}\text { Cronbach's } \alpha \\
\text { Value }\end{array}$ & $\begin{array}{l}\text { C.R. } \\
\text { Value }\end{array}$ & $\begin{array}{c}\text { AVE } \\
\text { Value }\end{array}$ & Communality & $\begin{array}{c}\text { Factor } \\
\text { Loading }\end{array}$ \\
\hline \multirow{3}{*}{$\mathbf{B A}$} & BA 2 & \multirow{3}{*}{4.281} & \multirow{3}{*}{0.402} & \multirow{3}{*}{0.693} & \multirow{3}{*}{0.828} & \multirow{3}{*}{0.617} & \multirow{3}{*}{0.617} & 0.724 \\
\hline & BA 3 & & & & & & & 0.778 \\
\hline & $\mathbf{B A}^{2}$ & & & & & & & 0.850 \\
\hline \multirow{4}{*}{ BT } & BT 1 & \multirow{4}{*}{4.441} & \multirow{4}{*}{0.629} & \multirow{4}{*}{0.786} & \multirow{4}{*}{0.863} & \multirow{4}{*}{0.614} & \multirow{4}{*}{0.614} & 0.770 \\
\hline & BT 2 & & & & & & & 0.851 \\
\hline & BT 3 & & & & & & & 0.866 \\
\hline & BT $^{2}$ & & & & & & & 0.624 \\
\hline \multirow{8}{*}{ BS } & BS 1 & \multirow{8}{*}{4.264} & \multirow{8}{*}{0.5482} & \multirow{8}{*}{0.874} & \multirow{8}{*}{0.898} & \multirow{8}{*}{0.526} & \multirow{8}{*}{0.526} & 0.780 \\
\hline & BS 2 & & & & & & & 0.755 \\
\hline & BS 3 & & & & & & & 0.741 \\
\hline & BS $^{2}$ & & & & & & & 0.732 \\
\hline & BS 5 & & & & & & & 0.769 \\
\hline & BS 6 & & & & & & & 0.720 \\
\hline & BS 7 & & & & & & & 0.688 \\
\hline & BS 8 & & & & & & & 0.598 \\
\hline \multirow{12}{*}{ BE } & BE 1 & \multirow{12}{*}{4.384} & \multirow{12}{*}{0.000} & \multirow{12}{*}{0.910} & \multirow{12}{*}{0.923} & \multirow{12}{*}{0.500} & \multirow{12}{*}{0.500} & 0.543 \\
\hline & BE 2 & & & & & & & 0.677 \\
\hline & BE 3 & & & & & & & 0.713 \\
\hline & $\mathrm{BE}^{2}$ & & & & & & & 0.701 \\
\hline & BE 5 & & & & & & & 0.754 \\
\hline & BE6 & & & & & & & 0.736 \\
\hline & BE7 & & & & & & & 0.732 \\
\hline & BE8 & & & & & & & 0.743 \\
\hline & BE9 & & & & & & & 0.722 \\
\hline & BE10 & & & & & & & 0.716 \\
\hline & BE11 & & & & & & & 0.718 \\
\hline & BE12 & & & & & & & 0.705 \\
\hline
\end{tabular}

Note: $\mathrm{BA}=$ Brand Attachment; BT = Brand Trust; BS = Brand Satisfaction; BE = Brand Experience; C.R.: Composite Reliability; AVE: Average Variance Reliability

*Scores: 1 - Strongly Disagree; 3 - Neutral; 5 - Strongly Agree

As can be seen in Table 2, all items have loadings greater than 0.6 (Nunnally \& Bernstein, 1994), indicating that they explain at least $60 \%$ of what they expected to measure (convergent validity). The lowest AVE value is 0.612 which exceeds the recommended 0.5 (Fornell \& Larcker, 1981) - an indication of the existence of discriminant validity. However, to guarantee sufficient discriminant validity between the research constructs, the square root of the Average Variance Extracted (AVE) of each factor should exceed the correlations between that factor and all other factors (Fornell \& Larcker, 1981). In this study, the least squared root of AVE is 0.782 while the highest inter-construct correlation value is 0.610 . Therefore, this further confirms the existence of discriminant validity. Using the composite reliability (CR) value and Cronbach's alpha value, the measurement instruments reliability was assessed and the lowest values are 0.894 and 0.842 , respectively, which exceeds the recommended acceptable value of 0.7 (Nunnally \& Bernstein, 1994). All in all, these results confirm the reliability and validity of the measurement used in this study.

Table 3: Inter-Construct Correlation Matrix

\begin{tabular}{|l|c|c|c|c|}
\hline \multicolumn{1}{|c|}{ Research Constructs } & BA & BT & BS & BE \\
\hline Brand Attachment (BA) & 1.0000 & & & \\
\hline Brand Trust (BT) & 0.6033 & 1.0000 & & \\
\hline Brand Satisfaction (BS) & 0.5857 & 0.7618 & 1.0000 & \\
\hline Brand Experience (BE) & 0.5529 & 0.6895 & 0.6976 & 1.0000 \\
\hline
\end{tabular}

Note: $\mathrm{BA}=$ Brand Attachment; $\mathrm{BT}=$ Brand Trust; $\mathrm{BS}=$ Brand Satisfaction; $\mathrm{BE}=$ Brand Experience

Smart PLS software does not provide goodness-of-fit measures for the full path model like LISREL and AMOS, but it provides only $\mathrm{R}^{2}$ values for the dependent variables. However, a method to calculate a global 
goodness-of-fit (GoF) measure was proposed by Amato, Vinzi and Tenenhaus (2004), and this method takes into account both the quality of the measurement model and the structural model (Tenenhaus, Vinzi, Chatelin \& Lauro, 2005; Streukens, 2008). The global goodness-of-fit (GoF) statistic was calculated using the following equation:

$\mathrm{GoF}=\sqrt{\overline{\mathrm{AVE}} * \overline{\mathrm{R}^{2}}}$

where $\overline{\mathrm{AVE}}$ represents the average of all AVE values for the research variables and $\overline{\mathrm{R}^{2}}$ represents the average of all $\mathrm{R}^{2}$ values in the full path model.

The calculated global goodness-of-fit (GoF) is 0.53 , which exceeds the recommended threshold of GoF > 0.36 suggested by Wetzels, Odekerken-Schröder \& van Oppen (2009). Thus, this study concludes that the research model provides an overall goodness-of-fit.

\subsection{Testing of the Hypotheses}

The results in Table 4 and Figure 2 provide support for all five (5) hypotheses. Hypothesis 1 posited a positive relationship between brand experience and brand satisfaction, while Hypothesis 2 posited a positive association between brand experience and brand trust. Consistent with Hypothesis 1 and 2, results indicated that higher levels of brand experience will lead to higher levels of brand satisfaction (0.698) and brand trust $(0.308)$.

The standardized coefficients of brand satisfaction and brand trust (0.547) are positive and significant. This is consistent with the prediction of $\mathrm{H} 3$ and is supported. Thus, a higher level of brand satisfaction is associated with higher levels of brand trust. The results in Table 4 and Figure 2 are in line with $\mathrm{H} 4$ and support the reasoning that the higher the levels of brand trust the customer has, the higher their brand attachment $(0.301)$. Therefore, H4 is strongly supported. Finally, the standardized coefficient of brand trust for brand attachment is positive and significant (0.374). This is consistent with the predictions of H5 - higher levels of brand trust by customers are associated with their higher levels of brand attachment. This seemingly robust result indicates the strength of brand attachment that result when the customers trust a brand. Therefore, H5 is strongly supported.

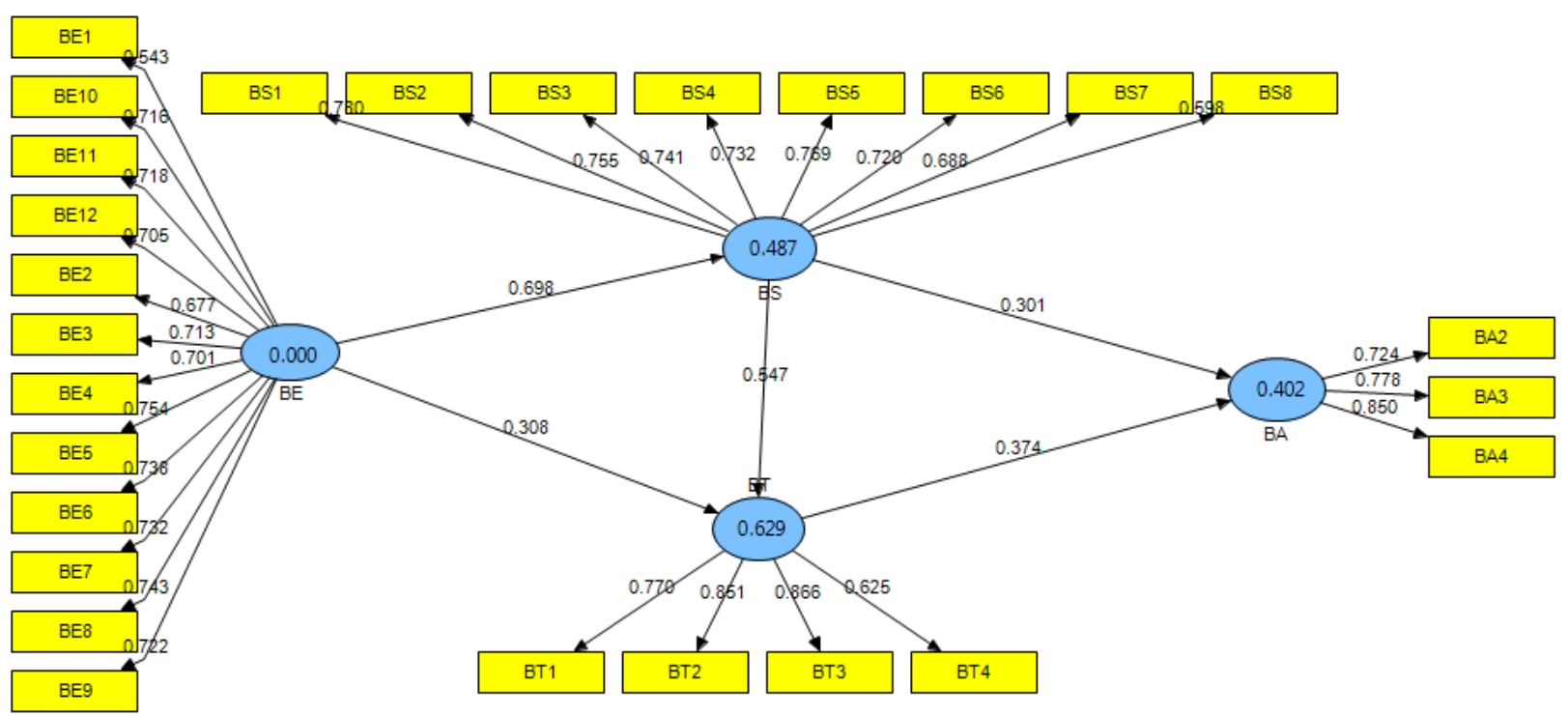

Figure 2: Measurement and Structural Model Results

Note: $\mathrm{BA}=$ Brand Attachment; $\mathrm{BT}=$ Brand Trust $\mathrm{BS}=$ Brand Satisfaction; $\mathrm{BE}=$ Brand Experience 
Table 4 provides the T-statistics for the hypothesised relationships. The minimum t-statistics for the path coefficients is 2.381 and therefore exceeds the recommended threshold of 2 . This means that all the posited positive relationships are supported and are statistically significant.

Table 4: Results of Structural Equation Model Analysis

\begin{tabular}{|lcccc|}
\hline \multicolumn{1}{|c}{ Proposed Hypothesis Relationship } & Hypothesis & $\begin{array}{c}\text { Path } \\
\text { Coefficients }\end{array}$ & T-Statistics & $\begin{array}{c}\text { Rejected/ } \\
\text { Supported }\end{array}$ \\
\hline Brand Experience (BE) $\rightarrow$ Brand Satisfaction (BS) & H1 & 0.698 & 13.735 & Supported \\
Brand Experience (BE) $\rightarrow$ Brand Trust (BT) & H2 & 0.308 & 3.529 & Supported \\
Brand Satisfaction (BS) $\rightarrow$ Brand Trust (BT) & H3 & 0.547 & 6.478 & Supported \\
Brand Satisfaction (BS) $\rightarrow$ Brand Attachment (BA) & $\mathrm{H}^{2}$ & 0.301 & 2.381 & Supported \\
Brand Trust (BT) $\rightarrow$ Brand Attachment (BA) & H5 & 0.374 & 3.580 & Supported \\
\hline
\end{tabular}

Note: $\mathrm{BA}=$ Brand Attachment; BT = Brand Trust; BS = Brand Satisfaction; BE = Brand Experience

\subsection{CONCLUSION AND DISCUSSION}

The purpose of this study was to investigate the influence of brand experience on brand satisfaction, brand trust and, consequently, brand attachment. In particular, five hypotheses were postulated. To test the proposed hypotheses, data were collected from Gauteng Province in South Africa. The empirical results supported all the posited research hypotheses in a significant way.

Important to note about the study findings is the fact that brand experience has stronger effects on brand satisfaction (0.698) than on brand trust (0.308). However, brand satisfaction strongly influences relationship brand trust (0.547). Notably, too, the relationship between brand trust and brand attachment is robust (0.374). By implication, this finding indicates that brand experience can have strong influence on brand trust and brand attachment via brand satisfaction. Perhaps this could be due to the fact that customers are likely to trust and be more attached to brands when they are satisfied with the brands in the first place - which sounds logical.

\subsection{Implications of the Study}

When customers or consumers are attached to a brand, they are likely to repurchase that brand, hence contributing to a firm's profitability. Therefore, in order to ensure customer brand attachment, managers ought to invest in strategies that foster brand satisfaction and brand trust. The current study is an attempt to investigate the influence of brand experience as a predictor of brand satisfaction and trust, which eventually leads to brand attachment in an often most neglected context - the African context. By and large, the findings of this empirical study are expected to have provided fruitful implications to both practitioners and academicians.

On the academic side, this study makes a significant contribution to the brand management literature by systematically exploring the impact of brand experience on brand satisfaction, brand trust and brand attachment in South Africa. Overall, the current study findings provide tentative support to the proposition that brand experience, brand satisfaction and brand trust should be recognized as significant antecedents for gaining and sustaining brand attachment in South Africa.

On the practitioners' side, the important influence of brand experience and mediating role of brand satisfaction and brand trust in South Africa is highlighted. This study therefore submits that marketers can benefit from the implications of these findings. For instance, given the robust relationship between brand experience and brand satisfaction (0.698), and also between brand satisfaction and brand trust (0.547), marketers ought to pay attention to both brand experience and brand satisfaction in order to build customer brand trust. For example, by improving the quality of brands and supplying them accompanied with quality service, customers are likely to be satisfied and trust such brands. Eventually, the customers will become attached to a brand that satisfies their needs and they perceive to be trustworthy.

\subsection{Limitations and Future Research}

Despite the usefulness of this study aforementioned, the research has its limitations. First and most significantly, the study can be strengthened by increasing the sample size and including participants in other 
geographical areas. Second, the current study was limited to South Africa. For results comparison, subsequent researches should contemplate replicating this study in other developing countries. Finally, the present study did not examine such factors as brand involvement and brand loyalty. Future studies should focus on other antecedents and their potential effects on brand attachment. All in all, these suggested future avenues of study stand to immensely contribute new knowledge to the existing body of brand management literature in Africa - a context that is often most neglected by some researchers in developing countries.

\section{AUTHOR INFORMATION}

Dr. Richard Chinomona is a Senior Lecturer and Facilitator of Research Methodology at Vaal University of Technology, Faculty of Management Sciences - Department of Logistics. He is a holder of six degrees and has published extensively in various international peer-reviewed journals. E-mail: $\underline{\text { rchinos@hotmail.com }}$

\section{REFERENCES}

1. Albert, N, Merunka, D., \& Valette-Florence, P. (2008). When consumers love their brands: Exploring the concept and its dimensions. Journal of Business Research, 61(11): 1062-1075.

2. Amato, S., Esposito V.V. \& Tenenhaus, M. (2004). A global goodness-of-fit index for PLS structural equation modeling, France: Oral Communication to PLS Club, HEC School of Management.

3. Arnold, M.J., Reynolds, K.E., Ponder, N., \& Lueg, J.E. (2005). Customer Delight in a Retail Context: Investigating Delightful and Terrible Shopping Experiences. Journal of Business Research, 58(8), 113245.

4. Bell, D.C. (2010). The dynamics of connection: How evolution and biology create care-giving and attachment. Lanham, MD: Lexington.

5. Bhattacharya, C.B., \& Sen, S. (2003). Consumer-company identification: A framework for understanding consumers' relationships with companies. Journal of Marketing, 67(2), 76-88.

6. Bouhlel O., Mzoughi N., Hadiji D., \& Slimane I. B. (2009). Brand Personality and Mobile Marketing: An Empirical Investigation, World Academy of Science, Engineering and Technology, Proceedings, Tokyo, Japan, issue 53, p. 703-710.

7. Brakus, J.J., Schmitt, B.H. \& Zarantonello L. (2009). Brand Experience; What Is It? How Is It Measured? Does It Affect Loyalty? Journal of Marketing, 73, 52-68.

8. Brakus, J.J., Schmitt, B.H., \& Zhang, S. (2008). "Experiential Attributes and Consumer Judgments," in Handbook on Brand and Experience Management, Bernd H. Schmitt and David Rogers, eds. Northampton, MA: Edward Elgar.

9. $\quad$ Bowlby, J. (1979). The making and breaking of affectional bonds. London: Tavistock.

10. Büschken, J. (2004). Higher Profits Through Customer Lock-In: A Roadmap. New York, NY.

11. Carroll, B., \& Ahuvia, A. (2006). Some antecedents and outcomes of brand love. Marketing Letters, 17(2), 79-89.

12. Chattopadhyay, A \& Laborie, J. (2005). Managing Brand Experience: The Market Contact Audit. Journal of Advertising Research, 45(1), 9-16

13. Chaudhuri, A., \& Holbrook, B.M. (2001). The Chain of Effects From Brand Trust and Brand Affects to Brand Performance: The Role of Brand Loyalty. Journal of Marketing, 65, 81-93

14. Chin, W.W, \& Newsted, P.R. (1999). Structural Equation Modeling analysis with Small Samples Using Partial Least Squares. In Rick Hoyle (Ed.), Statistical Strategies for Small Sample Research, Sage Publications, pp. 307-341. Thousand Oaks, CA: Sage

15. Chiu, C. M., Huang, H. Y., \& Yen, C. H. (2010). Antecedents of online trust in online auctions. Electronic Commerce Research and Application, 9, 148-159.

16. Christodoulides G, De Chernatony L, Furrer O, Shiu E, Abimbola T. (2006). Conceptualising and measuring the equity of online brands. Journal of Marketing Management, 22(7/8):799-825.

17. Cooil, B., Keiningham, T. L., Aksoy, L., \& Hsu, M. (2007). A longitudinal analysis of customer satisfaction and share of wallet: Investigating the moderating effect of customer characteristics. Journal of Marketing, 71(1), 67-83. 
18. Ercis, A., Unal, S., Candan, F.B. \& Yildrinm, H. (2012). The effect of brand satisfaction, trust and brand commitment on loyalty and repurchase intentions. Procedia - Social and Behavioral Sciences, 58, 1395 1404.

19. Fedorikhin, A., Park, C. W., \& Thomson, M. (2008). Beyond fit and attitude: The effect of emotional attachment on consumer responses to brand extensions. Journal of Consumer Psychology, 18(4), 281-291.

20. Flavian, C., \& Guinaliu, M. (2006). Consumer trust, perceived security and privacy policy: Three basic elements of loyalty to a web site. Industrial Management \& Data Systems, 106(5), 601-620.

21. Fornell, C., \& Larcker, V. F. (1981). Evaluating structural equation models with unobservable variables and measurement error. Journal of Marketing Research, 18, 39-50.

22. Gefen, D., Karahanna, E., \& Straub, D. W. (2003). Trust and TAM in online shopping: An integrated model. MIS Quarterly, 27(1), 51-90.

23. Gillath, O., Shaver, P. R., Baek, J-M., \& Chun, D. S. (2008). Genetic correlates of adult attachment style. Personality and Social Psychology Bulletin, 34(10): 1396-1405

24. Grace, D., \& O'Cass, A. (2004). Examining service experiences and post-consumption evaluations. Journal of Services Marketing. 18(6), 450-461.

25. Grisaffe, D.B., \& Nguyen, H.P. (2011). Antecedents of emotional attachment to brands. Journal of Business Research, 64(10): 1052-1059.

26. He, H., Li, Y., \& Harris, L. (2012). Social identity perspective on brand loyalty. Journal of Business Research, 65, 648-657

27. Janda, S, \& Ybarra, A. (2006). Do product and consumer characteristics affect the relationship between online experience and customer satisfaction? Journal of Internet Commerce, 4(4): 133-51.

28. Johar, G. V., Sengupta, J., \& Aaker, J.L. (2005). Two roads to updating brand personality impressions: Trait versus evaluative inferences. Journal of Marketing Research, 42(4): 458-469.

29. Jones, M.A. \& Suh, J. (2000). Transaction-Specific Satisfaction and Overall Satisfaction: An Empirical Analysis. The Journal of Services Marketing, 14(2), 147-159.

30. Joy, A., \& John, S. (2003). Speaking of art as embodied imaginations: A multi-sensory approach to understanding aesthetic experience. Journal of Consumer Research, 30, 259-82.

31. Keh, H.T., Nguyen, T.T.M., \& Ng, H.P. (2007). The effects of entrepreneurial orientation and marketing information on the performance of SMEs. Journal of Business Venturing, 22, 592-611

32. Kim, H. (2005). Consumer profiles of apparel product involvement and values. Journal of Fashion Marketing and Management, 9, 207-220.

33. Kim, M. J., Chung, N., \& Lee, C. K. (2011). The effect of perceived trust on electronic commerce: Shopping online for tourism products and services in South Korea. Tourism Management, 32, 256-265.

34. Koçoglu, I., Imamoglu, S.Z., Ince, H., \& Keskin, H. (2011). The effect of supply chain integration on information sharing: Enhancing the supply chain performance. Procedia - Social and Behavioral Sciences, 24, 1630-1649.

35. Koufaris, M. (2002). Applying the technology acceptance model and flow theory to online consumer behavior. Information Systems Research, 13(2), 205-223.

36. Kuenzel, S. \& Halliday, V.S. (2008). Investigating antecedents and consequences of brand identification. Journal of Product and Brand Management, 17(5): 293-304.

37. Liljander, V., Polsa, P., \& van Riel, A. (2009). Modelling consumer responses to an apparel store brand: Store image as a risk reducer. Journal of Retailing and Consumer Services, 16(4): 281-290.

38. Mandel, N \& Johnson, E.J. (2002). When Web Pages Influence Choice: Effects of Visual Primes on Experts and Novices. Journal of Consumer Research, 39, 1-39.

39. McAlexander, J.H., Schouten, J.W., \& Koenig, H.F. (2002). Building brand community. The Journal of Marketing, 66(1), 38-54.

40. Meyer, C \& Schwager, A. (2007). Understanding customer experience. Harvard Business Review, 85(6): $116-26$.

41. Nam, J., Ekinci, Y., \& Whyatt, G. (2011). Brand equity, brand loyalty and customer satisfaction. Annals of Tourism Research. 38(3): 1009-1030.

42. Nguyen, C.L., \& John, D.R. (2005). The Development of Self-Brand Connections in Children and Adolescents. Journal of Consumer Research, 32, 119-29.

43. Nunnally, J. C., \& Bernstein, I. H. (1994). Psychometric theory. 3rd ed. Sydney, Australia7 McGraw Hill. 
44. Ofir, C., \& Simonson, I. (2007). The Effect of Stating Expectations on Customer Satisfaction and Shopping Experience. Journal of Marketing Research, 44(1), 164-174.

45. Pappu, R., \& Quester, P. (2006). Does customer satisfaction lead to improved brand equity? An empirical examination of two categories of retail brands. The Journal of Product and Brand Management, 15(1), 4 14.

46. Park, C. W., Macinnis, D. J., \& Priester, J. (2009). Brand attachment: Construct consequences and causes. Boston: Now Publishers.

47. Park, C., Maclnnis, D. J., Priester, J., Eisingerich, A. B., \& Lacobucci, D. (2010). Brand attachment and brand attitude strength: Conceptual and empirical differentiation of two critical brand equity drivers. Journal of Marketing, 74(6), 1-17.

48. Park, C.W. \& MacInnis, D.J. (2006). What's in and What's Out: Questions on the Boundaries of the Attitude Construct. Journal of Consumer Research, 33(1): 16-18.

49. Parish, J. T., \& Holloway, B. B. (2010). Consumer relationship proneness: A reexamination and extension across service exchanges. Journal of Services Marketing, 24(1), 61-73.

50. Patterson, P.G., Johnson, L.W. \& Spreng, R.A. (1997). Modeling the determinants of customer satisfaction for business-to-business professional services. Journal of the Academy of Marketing Science, 25(1), 4-17.

51. Pawle, J., \& Cooper, P. (2006). Measuring emotions: Lovemarks, the future beyond brands. Journal of Advertising Research, 46(1): 38-48.

52. Ringle, C. M., Wende, S., \& Will, A. (2005). Smart PLS 2.0 M3. Available at http:// www.smartpls.de

53. Ruyter, K, Moorman, L \& Lemmink, J. (2001). Antecedents of commitment and trust in customer supplier relationships in high technology markets, Industrial Marketing Management, 30, 271-286.

54. Sahin, A., Zehir, C., \& Kitapçi, H. (2011). The Effects Of Brand Experiences, Trust And Satisfaction On Building Brand Loyalty; An Empricial Research On Global Brands, The $7^{\text {th }}$ International Strategic Management Conference, Paris-France.

55. Schau, J. H., Muniz, M. A., \& Arnould, J. E. (2009). How brand community practices create value. Journal of Marketing, 73(5), 30-51.

56. Schmitt, B.H. (2003). Customer Experience Management. New York: John Wiley \& Sons.

57. Shaw, C \& Ivens, J. (2002). Building Great Customer Experiences. Basingstoke: Palgrave Macmillan.

58. Simpson, J. A., Collins, W. A., Tran, S., \& Haydon, K. C. (2007). Attachment and the experience and expression of emotions in romantic relationships: A developmental perspective. Journal of Personality and Social Psychology, 72(2), 355-367.

59. Smith, S. \& Wheeler, J. (2002). Managing the Customer Experience. Financial Times Prentice Hall.

60. Streukens, S. (2008). On the use of partial least squares path modeling in organizational research: an overview and illustration of its possibilities. Working Paper, Hasselt University, Hasselt.

61. Suh, B., \& Han, I. (2003). The Impact of Customer Trust and Perception of Security Control on the Acceptance of Electronic Commerce. International Journal of Electronic Commerce, 7(3): 135-161.

62. Tenenhaus, M., Vinzi, V. E., Chatelin, Y. -M., \& Lauro, C. (2005). PLS Path Modeling. Computational Statistics and Data Analysis, 48(1), 159-205.

63. Thomson, M. (2006). Human Brands: Investigating Antecedents to Consumers' Strong Attachments to Celebrities. Journal of Marketing, 70, 104-119.

64. Thomson, M., MacInnis, D.J., \& Park, C.W. (2005). The Ties That Bind: Measuring the Strength of Consumers' Attachments to Brands. Journal of Consumer Psychology, 15(1): 77-91.

65. Tsai, S-P. (2011). Fostering international brand loyalty through committed and attached relationships. International Business Review, 20, 521-534.

66. Veryzer, R.W., \& Hutchinson, JW. (1998). The Influence of Unity and Prototypicality on Aesthetic Responses to New Product Designs. Journal of Consumer Research, 24(4), 374-394.

67. Wang, Y. D., \& Emurian, H. H. (2005). An overview of online trust: Concepts, elements, and implications. Computers in Human Behavior, 21(1), 105-125.

68. Whang, Y.-O., Allen, J., Sahoury, N., \& Zhang, H. 2004. Falling in Love with a Product: The Structure of a Romantic Consumer-Product Relationship. Advances in Consumer Research, 31(1), 320-327.

69. Wetzels, M., Odekerken-Schröder, G., \& Van Oppen, C. (2009). Using PLS path modeling for assessing hierarchical construct models: guidelines and empirical illustration. Management Information Systems Quarterly, 33(1), 177-195. 
70. Yoon, S.J. (2002). The antecedents and consequences of trust in online-purchase decisions. Journal of Interactive Marketing, 16(2): 47-63.

71. Zhou, Z., Zhang, Q., Su, C., \& Zhou, N. (2012). How do brand communities generate brand relationships? Intermediate mechanisms. Journal of Business Research, 65(7): 890-895. 


\section{APPENDIX}

\section{MEASUREMENT INSTRUMENTS}

\section{Brand Experience}

This brand makes a strong impression on my visual sense or other senses.

I find this brand interesting in a sensory way.

This brand does not appeal to my senses.

This brand induces feelings and sentiments.

I do not have strong emotions for this brand.

This brand is an emotional brand.

I engage in physical actions and behaviors when I use this brand.

This brand results in bodily experiences.

This brand is not action oriented.

I engage in a lot of thinking when I encounter this brand.

This brand does not make me think.

This brand stimulates my curiosity and problem solving.

\section{Brand Satisfaction}

I am very satisfied with the service provided by this brand.

I am very satisfied with this brand.

I am very happy with this brand.

This brand does a good job of satisfying my needs.

The service-products provided by this brand is very satisfactory.

I believe that using this brand is usually a very satisfying experience.

I made the right decision when I decided to use this brand.

I am addicted to this brand in some way.

\section{Brand Trust}

I trust this brand.

I rely on this brand.

This is an honest brand.

This brand is safe.

\section{Brand Attachment}

I am strongly passionate about the brand.

The brand induces strong passion in me.

I long to put the brand into my possession.

I may make necessary sacrifices to acquire the brand. 